\title{
НЕКИ АСПЕКТИ МОБИЛНИХ АПЛИКАЦИЈА ЗА ФАКУЛТЕТСКЕ БИБЛИОТЕКЕ
}

Сажетак: Мобилне технологије и рачунари отворили су нове хоризонте и наметнули нове изазове у глобализованом друштву. Узајамно прожимање мобилних телефона и образовања нужно је наметнуло и потребу за мобилним апликацијама у контексту библиотека и библиотечких садржаја. Специфичне мобилне апликације данас помажу корисницима да се боље сналазе у библиотечком окружењу. Ми смо се фокусирали на мобилне апликације за факултетске библиотеке. Први део рада пружа опште уводне напомене. Други део рада представља дескриптивно оријентисано испитивање извесних општих карактеристика мобилних апликација и опис најважнијих обележја ових апликација. Трећи део је емпиријског карактера и износи нацрт испитивања анализе потреба студената Електротехничког факултета у Београду за мобилним апликацијама за библиотеке. У последњем делу износе се закључне напомене и предлажу прелиминарне смернице за превазилажење неких уочених изазова у коришћењу мобилних апликација за факултетске библиотеке.

Кључне речи: мобилни телефони, мобилне апликације, факултетска библиотека, мобилне апликације за библиотеке, анализа потреба, студенти, Електротехнички факултет.

\section{1. Уводне напомене}

Према литератури, интернет је друштву, а нарочито индустријски развијеним привредама, представио један скуп историјски јединствених изазова. ${ }^{1}$ Истовремено, огромне и брзе технолошке промене извршиле су

1 Neil Barrett, The State of the Cybernation: Cultural, Political and Economic Implications of the Internet (London: Kogan Page, 1997), 16. 
изузетан утицај на образовне системе. ${ }^{2}$ Овде, свакако, треба поменути потенцијал интернета, који, према литератури, не познаје границе. Међутим, истиче се и да су друштвени и политички изазови неограничени, па је стога то једна изузетна, али истовремено и забрињавајућа слика. ${ }^{3}$ У том смислу, чини се да спрега интернета и мобилних телефона пружа потенцијално велике могућности у различитим областима, па тако и у образовању и библиотекарству.

Поједини аутори истичу да су популаризација комуникационих технологија треће генерације, развој мобилног интернета и пад цена паметних телефона обезбедили чврсту основу за коришћење мобилних телефона за претраживање интернета, што је резултирало и порастом броја корисника мобилних телефона широм света. ${ }^{4}$ Следствено томе, са порастом употребе мобилних телефона, повећао се и број мобилних апликација, како општих, тако и специфичних, чак бисмо рекли, и уско специјализованих за посебне намене. ${ }^{5}$ У литератури се наводи како се и очекује да мобилни уређаји умногоме промене начин комуникације јер омогућавају проналажење података, као и разне видове комуникације на једном уређају. ${ }^{6}$ Чини нам се да се ова цитирана констатација у великој мери и остварила.

Мобилне апликације су већ стекле одрећени статус у оквиру формалног образовања, па би и учесници у процесу образовања (наставници, педагози итд.), према литератури која се бави наставом статистике, требало да посматрају технолошке алатке као легитимне продужетке когнитивних система и као партнере у социокултурној арени учионице. ${ }^{7}$ Према литератури, свеприсутношћу данашњих софистицираних мобилних уређаја приступ информацијама се умногоме померио са десктоп окружења ка

2 Rebecca Arzola and Stefanie Havelka, "Mobile App Usage Assessment in the Academic Library", The Charleston Advisor 18(2) (2016): 72.

3 Neil Barrett, The State of the Cybernation: Cultural, Political and Economic Implications of the Internet (London: Kogan Page, 1997), 16.

4 Qunyi Wei, Zhaoxin Chang and Qin Cheng, "Usability Study of the Mobile Library App: An Example from Chongqing University", Library Hi Tech 33(3) (2015): 340.

5 Овде вреди напоменути да се идеја мобилности јавила још у доба мобилних рачунара. Према литератури, мобилни gиіитиални комӣјуйер одређује се као „дигитални компјутер који може да се користи у транспортним средствима.” Видети: Vera Tasić i Ivan Bauer, Rečnik kompjuterskih termina, Treće izdanje (Beograd: Mikro knjiga, 1998), 246.

6 Fred D. Barnhart and Jeannette E. Pierce, "Becoming Mobile: Reference in the Ubiquitous Library", Journal of Library Administration 52 (2012): 560.

7 Dani Ben-Zvi, “Toward Understanding the Role of Technological Tools in Statistical Learning”, Mathematical Thinking and Learning 2(1\&2) (2000): 149. 
мобилном окружењу, а као део овог тренда појавили су се научни радови који подстичу библиотеке да и саме започну осмишљавање конкретних предлога за мобилне могућности. ${ }^{8}$

Неки аутори указују на значај мобилних телефона, нарочито у области управљања библиотекама. Осветљавајући системе за управљање библиотекама осетљиве на контекст, засноване на мобилној проширеној стварности, аутори истичу да је мобилна проширена стварност постала популарна управо захваљујући технолошком напретку паметних телефона и осталих мобилних уређаја, а посебно у области управљања библиотекама у контексту мобилне проширене стварности. ${ }^{9}$ Иако суочени са изазовима осетљивости на контекст, и упркос напорима да се изазови превазиђу и изнађу решења у овом домену, овакве и сличне тенденције сведоче о важности различитих апликација не само у области управљања библиотекама, већ и у многим другим аспектима мобилног савременог библиотекарства.

У овом контексту вреди напоменути да релевантну улогу имају и услуге дигиталних библиотека у мобилном рачунарству. Дигиталне библиотеке омогућавају онлајн приступ великом броју текстова и извора информација мултимедијалног садржаја на један интегрисан начин, а подаци дигиталних библиотека обухватају текстуални садржај, слике, фотографије, звук, видео, филмове и различите слајдове. ${ }^{10}$ Корисници дигиталних библиотека не обухватају само кориснике на рачунарима већ и на мобилним телефонима, тим пре, што је приступ услугама дигиталних библиотека сада много лакши и приступачнији.

У овом раду покушаћемо да осветлимо неке аспекте употребе апликација мобилних телефона, односно мобилних апликација, у контексту библиотеке. ${ }^{11}$ Посебно су нас занимала обележја мобилних апликација која се наводе у референтној литератури, а која утичу на то да ли и у којој мери потенцијални корисници користе дате мобилне апликације.

8 Ramona Broussard, Yongyi Zhou, and Matthew Lease, "Mobile Phone Search for Library Catalogs", Proceedings of the American Society for Information Science and Technology 47(1) (2010): 1 .

9 Adrian Shatte, Jason Holdsworth, and Ickjai Lee, "Mobile Augmented Reality Based ContextAware Library Management System”, Expert Systems with Applications 41 (2014): 2174.

10 Bharat Bhargava, Melliyal Annamalai, and Evaggelia Pitoura, "Digital Library Services in Mobile Computing", ACM SIGMOD Record, 24(4) (1995): 34.

11 У раду користимо семантичке јединице мобилне айликације и айликације за мобилне йетефоне као потпуно синонимне, без икаквог теоријског залагања и без жеље да прексриптивно арбитрирамо над једним или другим преводним еквивалентом. 
Структура рада је следећа. Други део представља кратак преглед мобилних апликација за библиотеку, углавном према литератури, али и уз додатке из сопствене праксе. Трећи део рада приказује резултате истраживања мањег опсега мотивисаног испитивањем анализе потреба студената Електротехничког факултета у погледу мобилних апликација за библиотеке. Коначно, у завршном делу износимо прелиминарне закључне напомене.

Пошто се у литератури помињу различите могућности примене апликација мобилних телефона у библиотекарству, у следећем, дескриптивно оријентисаном делу, пружићемо преглед савремених токова и праваца на основу релевантне и анализиране литературе о овој теми.

\section{Кратак преглед мобилних апликација за библиотеке}

У литератури се констатује да мобилне апликације и веб-сајтови постају значајни будући да паметни телефони и таблет уређаји имају широку примену, па стога многи универзитети развијају сопствене мобилне апликације, и веб-сајтове прилагођене мобилним телефонима. ${ }^{12}$ Надаље, анализирајући паметне телефоне и мобилне технологије и њихову улогу у факултетским библиотекама, поједини аутори као почетну тачку наводе смернице у складу са којима су мобилне технологије и паметни телефони изменили начине на које користимо, делимо и стварамо информације, али упркос брзини којом су ове технологије дочекане, академска заједница их је прилично споро прихватала. ${ }^{13}$ Управо се могућност распрострањеније употребе мобилних апликација у библиотекарству и библиотекама налази и у предлогу цитираног аутора, који закључује да је неопходно да сами библиотекари препознају и анализирају трендове мобилних апликација, као и да изнађу стратешке одговоре за новонастале изазове.

Није изненађујуће да се мобилне апликације у библиотекама доводе у везу са услугама које се пружају у библиотекама, па су онда и условљене специфичним особинама ових услуга. Погледајмо, за тренутак, како се термин мобилне айликащије одређује у литератури. Апликација (енгл. арр),

12 Robin E. Miller, Bryan S. Vogh, and Eric J. Jennings, "Library in an App: Testing the Usability of Boopsie as a Mobile Library Application", Journal of Web Librarianship 7 (2014): 142.

13 Geoffrey Little, "Keeping Moving: Smart Phone and Mobile Technologies in the Academic Library”, The Journal of Academic Librarianship 37(3) (2011): 267. 
или мобилна апликација, концизно се одређује као софтвер који углавном функционише на мобилном уређају, уз напомену да данашњи паметни телефони нуде корисницима мноштво апликација. ${ }^{14}$ Цитирани аутори указују и на обележја мобилних апликација које их чине функционалним и корисним, нарочито у домену библиотеке, па ћемо их и погледати у наставку.

Наиме, мобилне апликације би требало да садрже софтвер или пак скуп програма који функционишу на мобилном уређају и извршавају извесне задатке за корисника. Управо се ова функционалност огледа у томе што се може приступити разноврсним и бројним изворима информација или пак многобројним услугама без потребе да се отвара веб-претраживач. Наравно, потребан је и одговарајући и прилагођен интерфејс који подразумева једноставно пријављивање на систем, као и лаку и једноставну регистрацију корисника. У литератури се констатује да треба узети у обзир нарочито ову главну особину мобилне апликације, па би стога целокупном садржају требало да се приступи на најједноставнији могући начин, водећи рачуна о безбедности података, а управо ово чини мобилне апликације толико популарним, не само међу стручном популацијом (међу библиотекарима и корисницима библиотека, или, у нашем случају, факултетских библиотека), већ и код инжењера који развијају софтвере. Као релевантно обележје наводе се добре перформансе апликације, а брзина апликација или пак учитавања стране не би требало да успорава кориснике, но овакве и сличне проблеме решава контрола квалитета мобилних апликација, што припада и примени паметних телефона и развоју софтвера. ${ }^{15}$

Мобилне апликације би требало да одлично управљају личним подацима и приватним информацијама корисника, како у контексту библиотеке, тако и приликом употребе за друге сврхе. Но, то излази из опсега овог испитивања, пошто се тиме, између осталог, баве софтверски инжењери. Такође, у литератури се од релевантних параметара наводи и важност добре техничке подршке као и благовремено ажурирање мобилних апликација у складу са потребама корисника библиотеке и самих библиотекара који уносе податке у библиотечку базу података. У том смислу, битно је да су подаци ажурирани и да заиста могу да одговоре на упите корисника мобилних апликација за библиотеке. Наравно, не може се пренебрегавати ни аналитика података мобилних апликација за библиотеке, нарочито с

14 Ajay Shanker Mishra, Jai Krishna Jha, and Sachin Kumar Umre, "Mobile App and the Library Services”, International Journal of Information Libraries \& Society 6(1) (2017): 27.

15 Ajay Shanker Mishra, Jai Krishna Jha, and Sachin Kumar Umre, "Mobile App and the Library Services”, International Journal of Information Libraries \& Society 6(1) (2017): 28. 
обзиром на то да, као што то се то наводи у литератури, аналитика података јесте суштинско обележје једне софтверске апликације. ${ }^{16}$ Следствено томе, инжењери који се баве развојем мобилних апликација свакако морају водити рачуна о интегрисању аналитике података у конкретне мобилне апликације, тим пре што нам ова врста података указује најоптималнији начин за побољшање мобилне апликације намењене библиотеци.

Узимајући у обзир наведена обележја мобилних апликација за библиотеке, као и друга обележја из литературе, извесни аутори класификују и саме мобилне апликације за потребе библиотеке и библиотекара. Те класификације су детаљно разрађене, а врше се према различитим параметрима. На пример, најпре се мобилне апликације деле на 1. апликације намењене читању садржаја (и то: апликације за читање електронских књига, скидање електронских књига из библиотеке, читање часописа и новина, дељење дигиталног садржаја итд.), 2. апликације за постизање продуктивности (и то: апликације за управљање датотекама у облаку, апликације за безбедно управљање лозинкама, за стварање спискова послова и обавеза, уређивање и управљање календаром, апликације за даљински приступ десктопу итд.), 3. апликације за истраживање и упућивање на одговарајућу литературу (и то: апликације за различите монолингвалне и билингвалне речнике, апликације за приватне претраживачке машине, за специјализоване претраживачке машине, апликације за конвертовање јединица, апликације за мапирање и 3Д мапирање итд.), 4. апликације за хватање бележака и писање (и то: апликације за управљање цитатима и библиографијама, апликације за хватање и организовање бележака, снимање гласа, снимање предавања, препознавање гласа итд.), 5. апликације за мултимедије (прецизније: за посете виртуелним музејима, цртање, креирање уметничких предмета, стварање фото-колажа, уређивање фотографија, идентификовање музичких комада итд.), 6. апликације за друштвене мреже, 7. за унапређење комуникације, 8. апликације за излазак из каталога библиотеке (прецизније: апликације за скенирање бар-кодова, за израде каталога мобилне библиотеке, за проширену реалност итд.), 9. апликације за професионални развој, да набројимо само неке које смо нашли у релевантној литератури. ${ }^{17}$

У литератури се наводи и подела мобилних апликација према алатима за развој апликација. Аутори наводе поделу на нативне, веб и хибридне

16 Ajay Shanker Mishra, Jai Krishna Jha, and Sachin Kumar Umre, "Mobile App and the Library Services", International Journal of Information Libraries \& Society 6(1) (2017): 28.

17 Nicole Hennig, Apps for Librarians: Using the Best Mobile Technology to Educate, Create, and Engage (Santa Barbara, California and Oxford, England: Libraries Unlimited, 2014), 9-153. 
апликације ${ }^{18}$. Нативне мобилне апликације су израђене помоћу скупа рачунарских алатки за развој апликације и програмског језика одређене мобилне платформе. Добра особина нативних апликација огледа се у чињеници да су израђене по мери за специфичну платформу, па сходно томе, пружају, скоро сасвим сигурно, оптималне резултате на датој платформи. С друге стране, веб-апликације се чине транспарентнијим у погледу платформе и датог оперативног система. Добра особина веб-апликација јесте лако покривање разних платформи. Коначно, хибридне апликације представљају нативне апликације намењене специфичној платформи.

Постоје разноврсне мобилне апликације, а навешћемо само неке обухваћене наведеном класификацијом мобилних апликација. Према литератури, те апликације су: Microsoft OneNote, Trello, LibAnywhere, Catch, EverNote, AccessMyLibrary, ArticleSearch, Inspiration Maps, EasyBib. ${ }^{19}$ Постоје мобилне апликације за управљање референцама, софтвер за управљање цитатима и индивидуалним библиографијама. Све ове апликације могу да олакшају увоз цитата из база података и са веб-сајтова. Затим, мобилне апликације могу да формирају и организују библиографску грађу и библиографије. Наравно, из угла корисности, посебно су драгоцене апликације за форматирање цитата за научне радове, као и за хватање бележака из чланака и чување у бази цитата. Наравно, незаобилазне су и апликације које чувају и организују документа у PDF формату, снимке екрана, графиконе, слике и различите датотеке које се користе у истраживању.

Из овог кратког дескриптивног дела закључујемо да су потенцијали употребе мобилних апликација у библиотеци велики, па стога могу имати конкретну примену и међу студентском популацијом ${ }^{20}$, тим пре што неки аутори наводе да су сада студенти мобилни и имају очекивања у погледу доступности универзитетских услуга док су у покрету. ${ }^{21}$ Цитирани аутори истичу да библиотеке и универзитети морају бити свесни потребе студената за мобилношћу, па би, стога, требало да укључе и развој овакве врсте

18 Ajay Shanker Mishra, Jai Krishna Jha, and Sachin Kumar Umre, "Mobile App and the Library Services", International Journal of Information Libraries \& Society 6(1) (2017): 29.

19 Овде нећемо описивати сваку од побројаних мобилних апликација због просторне ограничености, али и зато што за сваку од наведених постоје опширни описи и детаљни подаци на интернет сајтовима.

20 Ограничили смо се на употребу мобилних апликација за библиотеку међу студентском популацијом, будући да и сами предајемо на факултету, што не искључује могућност примене и код ученика основних и средњих школа.

21 Sally Wilson and Graham McCarthy, "The Mobile University: from the Library to the Campus", Reference Services Review 38(2) (2010): 225. 
мобилности у своје стратешко планирање. Они истичу и да су у првом плану изазови које постављају мобилни уређај, као што су мали екрани, тешкоће да се користе уређаји за унос података, између осталог. Ипак друге особине ових уређаја требало би да буду у жижи, нпр: могућност лаког преноса, погодност уређаја, уграђене камере и GPS могућности.

За наше истраживање посебно су занимљиве специјализоване мобилне апликације које имају намену у библиотеци. Према литератури, повећана употреба мобилних уређаја за приступ интернету изменила је, поред осталог, и понашање корисника специјализованих медицинских библиотека приликом претраге информација, па се управо у овим специјализованим библиотекама јавила потреба за развојем мобилних апликација које су оријентисане ка библиотеци. ${ }^{22}$

Занимљиви су и примери коришћења конкретних мобилних апликација у библиотекама у академском окружењу, као што је то пример апликације WeChat. Студенти Њујоршког универзитета у Шангају (енгл. New York University Shanghai), сателитском кампусу Њујоршког универзитета, имају прилике да користе мобилну апликацију WeChat за конкретне претраге у оквиру своје универзитетске библиотеке, па могу сазнати и податке о стању ажурирања библиотеке, летњем радном времену библиотеке, расположивости лаптопа за изнајмљивање и/или рад у библиотеци, а апликација се нарочито показала корисном за студенте који немају приступ друштвеним мрежама. ${ }^{23}$

Када се говори о коришћењу мобилних апликација намењених библиотекама, истраживачи углавном желе да испитају конкретне проблеме са којима се сусрећу корисници. У том смислу, креирају се упитници који, поред осталог, покушавају да пруже одговоре на следећа питања:

- Које су предности и трошкови размене код обезбеђивања прилагођених мобилних апликација за приступ каталогу библиотеке?

- Какве предности или мане нуде мобилни интерфејси за претраживање у поређењу са стандардним приступом заснованим на стандардним веб-прегледачима на мобилном уређају?

22 Eric Schnell, “The Mobile Medical Library - Is There an App for That?”, Journal of Electronic Resources in Medical Libraries 9(2) (2012): 147.

23 Raymond Pun, "WeChat in the Library: Promoting a New Virtual Reference Service Using a Mobile App”, Library Hi Tech News 32(6) (2015): 10. 
- Који се све трошкови јављају приликом развоја прилагођених мобилних апликација за приступ библиотечком каталогу?

- Које су типичне потребе корисника приликом претраге каталога библиотеке на мобилним уређајима ${ }^{24}$ итд.

Ово су само нека питања која истраживачи постављају како би у што бољој мери профилисали потребе корисника библиотеке (пре свега, академских корисника) и, сходно томе, допринели побољшању различитих перформанси мобилних апликација за библиотеке. Узимајући у обзир ове налазе из литературе, и слична истраживања, у следећем делу саопштавамо резултате једног истраживања мањег обима спроведеног на узорку студената Електротехничког факултета у Београду, имајући у виду њихове потребе приликом коришћења мобилних апликација за библиотеку.

\section{Анализа потреба на Електротехничком факултету у Београду}

Пошавши од констатација изнетих у релевантној литератури и ослонивши се на предности мобилних апликација за кориснике библиотека (попут: приступа за претрагу библиотечког каталога, проналажење информација о радном времену библиотеке, контакт информација библиотеке, интерактивне мапе библиотека, приступа апликацији Пийај библиотеекара, линкова за веб-сајтове прилагођене корисницима итд.) ${ }^{25}$, желели смо да и сами испитамо мотивисаност студената за коришћење мобилних апликација у контексту библиотеке. Истовремено смо желели да урадимо и анализу потреба у вези са мобилним апликацијама за библиотеке за студенте Електротехничког факултета у Београду.

Током 2010. године, аутор је и са̂м почео да, у својој наставној пракси енглеског језика за специфичне сврхе, користи различите апликације за мобилне телефоне, које су у то доба биле доступне. Пошто улога ових апликација у области методике наставе страног језика није предмет овог рада,

24 Ramona Broussard, Yongyi Zhou, and Matthew Lease, "Mobile Phone Search for Library Catalogs", Proceedings of the American Society for Information Science and Technology 47(1) (2010): 1 .

25 Ajay Shanker Mishra, Jai Krishna Jha, and Sachin Kumar Umre, "Mobile App and the Library Services”, International Journal of Information Libraries \& Society 6(1) (2017): 28. 
онда ћемо погледати оно што је произишло из интересовања за ову област. Наиме, занимало нас је да испитамо како и колико студенти користе апликације за мобилне телефоне у контексту Библиотеке Електротехничког факултета. Но пре него што кренемо на опис конкретног истраживања и анализе потреба, погледаћемо релевантне информације о Библиотеци Електротехничког факултета у Београду.

Историјски посматрано, најпре је основана Библиотека Катедре за електротехнику при Великој школи у Београду, и то 1894. године, а која је онда прерасла у Библиотеку Електротехничког факултета у Београду. Библиотека је специјализована у свим областима електротехнике, или специфичније, електронике, енергетике, телекомуникација, рачунарства, а бави се и набавком, обрадом, позајмицом, издавањем публикација, као и оспособљавањем за коришћење стручних и научних извора.

Фонд Библиотеке обухвата монографске публикације (издања иностраних књига намењена професорима, постдипломцима, дипломцима, и уџбеничку литературу намењену студентима), домаће и иностране серијске публикације, докторске дисертације и магистарске тезе. Према подацима из последње акредитације Електротехничког факултета, библиотечки фонд обухвата 20.709 монографских публикација на српском језику и 18.888 на страним језицима, укупно 39.597 монографија. Часописа на српском језику има 44.540, а на страним језицима 1.964, што чини укупно 46.504 часописа. Побројано је 689 уџбеника на српском језику и 112 уџбеника на страним језицима, тј. укупно 801 уџбеник. Коначно, свеукупан фонд броји 86.902 библиографске одреднице.

Библиотека је хардверски опремљена 1995. године. У базу података је унет целокупан фонд књига које се налазе у библиотеци, као и оних које су набављене после 1995. године, затим, свих часописа, магистарских радова и доктората. Они формирају електронски каталог који се води паралелно са лисним каталогом Библиотеке. Претраживање електронског каталога је на адреси http://biblioteka.etf.bg.ac.rs.

Ангажовањем и непрекинутим везама некадашњих студената са својим матичним факултетом, из свих делова света у Библиотеку стижу донације најновијих публикација доприносећи успостављању угледа и места који је Факултет одувек уживао, а обогаћењу фонда доприноси и програм Министарства просвете, науке и технолошког развоја финансирањем обједињене набавке страних часописа и база података. Сада ћемо погледати кратак синопсис нашег истраживања.

Током школске 2015/2016. и 2016/2017. године, извршили смо испитивање о употреби мобилних апликација за приступ каталогу библиотеке, као и различитих мобилних апликација које студенти користе. Наша 
анкета мотивисана је сличним, али опсежнијим и детаљнијим анкетама у оквиру истраживања наведених у релевантној литератури ${ }^{26}$ Истовремено, желели смо да урадимо анализу потреба студената Електротехничког факултета у Београду у вези са специфичним мобилним апликацијама за библиотеке које студенти користе.

Анкетирани су студенти са Одсека за софтверског инжењерство (СИ), и то $\mathrm{N}=120$ узраста $\mathrm{M=19}$ за школску 2015/16. и $\mathrm{N}=180$ узраста $\mathrm{M=19}$ за школску 2016/17. годину. ${ }^{27}$ Инструмент је био у виду анкетног листића, с тим што су неки студенти попуњавали анкету ручно, а неки електронским путем.

Оно што нас је занимало јесу следећи подаци:

- Да ли библиотека омогућава мобилни приступ у довољној мери?

- Шта би студенти додали/променили у том мобилном приступу?

- Да ли могу да приступе свим жељеним информацијама путем мобилног телефона?

- Које мобилне апликације користе за учење, а које за библиотеку?

- Да ли и у којој мери користе друштвене мреже за прибављање специфичних информација о библиотеци ЕТФ-а и о библиотекама које користе, или само користе званичне интернет стране библиотека?

- Које мобилне апликације користе за библиотеке генерално, а које за Библиотеку ЕТФ-а?

- Које мобилне апликације користе у читаоници Библиотеке и да ли им те апликације помажу и у којој мери у прикупљању и/или савлађивању градива?

Ово су била само нека питања на која смо желели да сазнамо одговоре. Поред ових примарних питања, која се у највећој мери односе на потребе студента као корисника библиотеке, била су додата и нека секундарна питања која се не морају нужно односити само на мобилне апликације у

26 Dresselhaus, Angela, and Flora Shrode, "Mobile Technologies and Academics: Do Students Use Mobile Technologies in Their Academic Lives and Are Librarians Ready to Meet This Challenge?", Information Technology and Libraries 31(2) (2012): 82-101.

27 Потребно је напоменути да истинитост навођења узраста у анкетном листићу (било штампаном, било електронском) нисмо накнадно проверавали, у смислу „спаривања” података наведених у анкетном листићу и података из званичног факултетског система, па стога следе и једнообразни подаци за узраст, односно, $\mathrm{M=19}$. Ипак, овај податак, свакако, не би требало ни да „одудара”, пошто је испитивање вршено у првом семестру прве године студија, када су студенти практично тек уписали Електротехнички факултет у Београду. Такође, у датом тренутку, није нам се чинило посебно релевантно да статистички утврдимо однос студената у анкети према полу. Све ово сматрамо да не утиче у некој значајној мери на укупну слику, која се може стећи. 
библиотекама, али нас су занимала. На пример, занимали су нас квалитет и брзина одзивног времена, уколико под одзивним временом подразумевамо оно што се у стандардној литератури на дату тему одређује као „[... време које протекне од тренутка када је корисник рачунарског система обавио неку радњу до тренутка када је примио одзив од рачунара ${ }^{28 ”}$. Наравно, овај параметар нас је занимао само у контексту коришћења мобилних апликација за библиотеку и у библиотеци. Анализирали смо попуњене штампане и електронске анкетне листиће и спровели статистичку анализу према стандардним процедурама.

Највећи број испитаника $(75,66 \%)$ одговорио је да мобилне апликације које користе за библиотеку омогућавају приступ релевантним садржајима које би хтели да погледају или им приступе, док је мањи део испитаника био мање задовољан овим могућностима (24,34\%). Међутим, овде вреди напоменути да су сличну констатацију навели како за могућности коришћења апликација за факултетску (задовољних процентуално 68,57\%, а делимично задовољних $31,43 \%$ ), тако и за све остале библиотеке које користе (задовољних 72,33\%, а делимично задовољних 27,67\%). Испитаници су навели да би променили могућност приступа преко неких мобилних апликација. Замерили су што не постоји адекватна оптимизација за мобилне телефоне и остале паметне уређаје (нпр. таблет), а такође су навели као негативну страну и мањак интерактивности, овде пре свега истакавши интерактивност у вези са електронским садржајима.

Већи део испитаника навео је да је задовољан комуникацијом на релацији „библиотекар - корисник библиотеке” (68,45\%), што иде у прилог констатацијама, изнетим у литератури, да су библиотекари потпуно у кораку са временом, пошто се прате најсавременије тенденције у библиотекарству и информатици. ${ }^{29}$ Библиотекари успешно користе најразноврсније мобилне али и остале апликације, и остварују ефикасну електронску комуникацију и спровођење библиотекарских услуга у академском

28 Valeri Ilingvort, Edvard L. Glejzer i Ijan C. Pajl, Oksfordski rečnik računarstva (Beograd: Nolit, 1990), 206.

29 Напомињемо да су питања за услуге библиотекара у библиотекама, у оквиру анкете, искључиво општег типа (нпр. добијање информација о радном времену библиотеке путем мобилних апликација, расположивост интерактивног коришћења каталога уз непосредно контактирање библиотекара путем електронске комуникације, углавном електронске поште итд.), па сматрамо да би резултати били много другачији да смо убацили и специфичнија питања која задиру више у удобност коришћења мобилних апликација и уопште приступа на даљину (нпр. анкетно питање „Да ли и колико можете да комуницирате са библиотекарима путем специфичних апликација?”). Но, оваква и слична питања изискују посебно и веће испитивање већег узорка и с њим скопчано истраживање и анализу потреба. 
миљеу. Испитаници су у највећој мери одговорили да најчешће користе апликације за приступ каталогу библиотечких јединица, затим за листање наставних материјала на интернет страницама предмета, или доступних електронских издања које нуде библиотеке. Главна замерка испитаника, као што смо већ имплицитно поменули, односи се на дигитализацију већег броја извора, и то не само књига, монографија итд. већ и аудио-визуелних садржаја.

Од мобилних апликација које су корисне за факултетску библиотеку, испитаници су издвојили најпре оне које могу да копирају и фотографишу изворе, а затим да даље манипулишу овим дигитализованим подацима, нпр. да претражују светске базе података, да проверавају информације, да их цитирају, конвертују у табеле, па чак и графичке приказе, на основу улазних података. У том смислу студенти су издвојили EverNote и Microsoft OneNote, затим апликацију Trello, која им помаже у организовању тимова, распореда и прегледа задатака који су урађени, који су у процесу израде или који се тек планирају. Наравно, поједини испитаници су користили и разне алтернативне апликације, но пошто предмет рада није компаративна анализа мобилних апликација, нећемо коментарисати тај део резултата анкете.

\section{Закључне напомене}

У раду се пошло од претпоставке да свеприсутност мобилних телефона условљава њихову употребу приликом коришћења библиотеке. У уводном делу дат је кратак преглед мобилних апликација, релевантних обележја, која се узимају у обзир приликом креирања ових апликација и пописане су неке апликације, углавном према литератури.

У наредном делу, аутор саопштава резултате мини-истраживања које је спровео током две школске године на ограниченом узорку студената Електротехничког факултета у Београду, у жељи да испита функционалност и оптималност мобилних употреба и да изврши анализу потреба својих студената у погледу мобилних апликација за библиотеку.

На основу резултата, утврђено је да су главни изазови: боља оптимизација интерфејса, већа динамичност у интеракцији и електронској комуникацији, дигитализовање већег електронског садржаја који би се учинио доступним путем мобилних апликација. Наравно, ово су само неки узорковани изазови, што не значи да не постоје још неки, можда и статистички релевантнији изазови. 
Ови налази су само прелиминарне природе и захтевају даља испитивања и статистичка истраживања на већим узорцима испитаника, но сматрамо да и овако скроман допринос може да осветли извесне аспекте мобилних апликација за факултетске библиотеке.

\section{Literatura}

1. Arzola, Rebecca and Stefanie Havelka. "Mobile App Usage Assessment in the Academic Library". The Charleston Advisor 18 (2) (2016): 71-73.

2. Barnhart Fred D., and Jeannette E. Pierce. "Becoming Mobile: Reference in the Ubiquitous Library”. Journal of Library Administration 52 (2012): 559-570.

3. Barrett, Neil. The State of the Cybernation: Cultural, Political and Economic Implications of the Internet. London: Kogan Page, 1997.

4. Ben-Zvi, Dani. "Toward Understanding the Role of Technological Tools in Statistical Learning". Mathematical Thinking and Learning 2 (1\&2) (2000): 127-155.

5. Bhargava, Bharat, Melliyal Annamalai, and Evaggelia Pitoura. "Digital Library Services in Mobile Computing". ACM SIGMOD Record, 24(4) (1995): 34-39.

6. Broussard, Ramona Yongyi Zhou, and Matthew Lease. "Mobile Phone Search for Library Catalogs". Proceedings of the American Society for Information Science and Technology 47(1) (2010): 1-4.

7. Dresselhaus, Angela, and Flora Shrode. "Mobile Technologies and Academics: Do Students Use Mobile Technologies in Their Academic Lives and Are Librarians Ready to Meet This Challenge?". Information Technology and Libraries 31 (2) (2012): 82-101.

8. Hennig, Nicole. Apps for Librarians: Using the Best Mobile Technology to Educate, Create, and Engage. Santa Barbara, California and Oxford, England: Libraries Unlimited, 2014.

9. Ilingvort, Valeri, Edvard L. Glejzer, i Ijan C. Pajl. Oksfordski rečnik računarstva. Beograd: Nolit, 1990.

10. Little, Geoffrey. "Keeping Moving: Smart Phone and Mobile Technologies in the Academic Library”. The Journal of Academic Librarianship 37 (3) (2011): 267-269.

11. Miller, Robin E., Bryan S. Vogh, and Eric J. Jennings. "Library in an App: Testing the Usability of Boopsie as a Mobile Library Application". Journal of Web Librarianship 7 (2014): 142-153.

12. Mishra, Ajay Shanker, Jai Krishna Jha, and Sachin Kumar Umre. "Mobile App and the Library Services". International Journal of Information Libraries \& Society 6(1) (2017): 27-32. 
13. Pun, Raymond. "WeChat in the Library: Promoting a New Virtual Reference Service Using a Mobile App”. Library Hi Tech News 32(6) (2015): 9-11.

14. Schnell, Eric. “The Mobile Medical Library - Is There an App for That?". Journal of Electronic Resources in Medical Libraries 9(2) (2012): 147-154.

15. Shatte, Adrian, Jason Holdsworth, and Ickjai Lee. "Mobile Augmented Reality Based Context-Aware Library Management System". Expert Systems with Applications 41 (2014): 2174-2185.

16. Tasić, Vera i Ivan Bauer. Rečnik kompjuterskih termina. Treće izdanje. Beograd: Mikro knjiga, 1998.

17. Wei, Qunyi, Zhaoxin Chang, and Qin Cheng. "Usability Study of the Mobile Library App: An Example from Chongqing University”. Library Hi Tech 33(3) (2015): 340-355.

18. Wilson, Sally, and Graham McCarthy. "The Mobile University: from the Library to the Campus". Reference Services Review 38(2) (2010): 214-232. 


\title{
Miloš D. Đurić
}

University of Belgrade

Faculty of Electrical Engineering

djuric@etf.bg.ac.rs

\section{SOME ASPECTS OF MOBILE APPLICATIONS FOR FACULTY LIBRARIES}

\begin{abstract}
With the advent of the Internet, as a global network, new challenges have appeared particularly due to technology improvement. In the meantime, mobile phones have provided new opportunities in educational settings and libraries thereby stimulating creation of specialized mobile apps for specific educational and library purposes. This paper reconsiders the question of mobile applications for library purposes, taking as a starting point the classifications proposed in the relevant literature on the subject. The paper is organized around the following sections: the first section is a brief overview of certain aspects of the Internet development, communication technology enhancement, and specific mobile phone usage. The second part is more descriptive in orientation since it provides the data on which our analysis was based, and describes the relevant features of mobile applications for libraries. The third part is more empirical in nature in that it outlines the applicability of the previously mentioned theoretical postulates to a group of practical challenges. By way of illustration, this part examines the utilization of mobile apps for the library based on concrete examples from the author's needs analysis for students at the Faculty of Electrical Engineering in Belgrade. The fourth part summarizes our findings.
\end{abstract}

Keywords: Mobile Phones, Mobile Applications, Faculty Library, Mobile Apps for the Library, Needs Analysis, Students, Faculty of Electrical Engineering.

Примљено: 6. маја 2020.

Прихваћено: 12. јуна 2020. 